\title{
AN ASSESSMENT OF THE ECONOMIC VIABILITY AND COMPETITIVENESS OF MODULAR REFINERY IN NIGERIA
}

\author{
N. O. Ogbon ${ }^{1, *}$, O. B. Otanocha ${ }^{2}$ and A. Rim-Rukeh ${ }^{3}$ \\ 1, Dept. of Petroleum Engr, Federal Univ. of Petroleum Resources, EFfurun, Delta State, NiGeria \\ 2, Dept. of Mechanical EngineEring, Fed. Univ. of Petroleum Resources, EFfurun, Delta State, NiGERIA \\ 3, Dept. of Environmental Mgt. \& Toxicology, Fed. Univ. of Pet. Resources, EfFurun, Delta State, Nigeria \\ E-mail addresses.1 ogbanap@gmail.com, ${ }^{2}$ otanocha.omonigho@fupre.edu.ng, 3 arimrukeh@yahoo.co.uk
}

\begin{abstract}
Will the establishment of modular refinery in Nigeria be economically viable to withstand global economc competitiveness by 2020? What are the likely prospects regarding the revamping of the present refineries in Nigeria to produce at an established capacity of 445,000 bpsd, and the coming on stream of the Dangote 650,000 bpsd refinery by 2020?. This paper provides analyses of the current state of the refining sector in Nigeria and the refining revolution that will take place within the next 3-5 years using data obtained from secondary sources. With a maintenance period of 31 days in a year and a PMS yield at $31.781 \%$ per barrel volume, the study revealed that with the four refineries in Nigeria working at full capacity for 334 days in a year, it can only produce $7.5 \times 10^{9}$ litres of PMS per annum. In the same vein the Dangote refinery, will yield about $11 \times 10^{9}$ litres of PMS. The import and supply analyses reveal an increase of 700,000,000 liter of PMS per year and $22.4 \times 10^{\circ}$ litres as the projected demand of PMS by 2020. The research further profiles financial analyses of a typical 10,000 bpsd modular refinery, with net income increasing from $\$ 39 \mathrm{M}$ in the first year to $\$ 49 \mathrm{M}$ in the fifth year, with dividends accumulating from $\$ 4 M$ in the first year to $\$ 30 M$ by the fifth year.
\end{abstract}

Key words:, modular refinery, Dangote refinery premium motor spirit, importation, supply, demand, economy

\section{INTRODUCTION}

By any standard, the petroleum sector play a key role in the Nigeria's economic growth and development. As of the year 2000, oil and gas exports accounted for more than $98 \%$ of export earnings and about $83 \%$ of Federal Government revenue, as well as generating more than $14 \%$ of its GDP. It also provides $95 \%$ of foreign exchange earnings, and about $65 \%$ of government budgetary revenues [1]. Modern industrial civilization depends on petroleum and its products $[2,3]$. In addition, the goal of developing countries is to exploit their natural resources and to supply foodstuffs for the burgeoning populations based on the assumption of petroleum products availability.

Most of the world's supply of petroleum comes from the Middle East, Nigeria, Angola, Libya, etc [4 - 6]. Petroleum is sold in the world market per oil barrels where a unit oil barrel (abbreviation bbl) is equivalent to 42 US gallons or about 159 litres [7]. Petroleum cannot be used in industry in its crude state; hence it is transformed into useful products such as liquefied petroleum gas (LPG), gasoline or petrol, kerosene, jet fuel, diesel oil and fuel oils [8]. This process of transformation is known as refining and it occurs in special facilities known as petroleum refineries (or oil refineries). The petroleum refining processes are primarily chemical engineering processes. An oil refinery is considered an essential part of the downstream side of the petroleum industry [9-11]. It is where crude oil is processed and refined into more useful products such as petroleum naphtha, gasoline or premium motor spirit (PMS) or petrol, diesel fuel, asphalt base, heating oil, kerosene, and liquefied petroleum gas. There is usually an oil depot (tank farm) at or near an oil refinery for the storage of incoming crude oil feedstock as well as bulk liquid products.

Nigeria's refining capacity is currently insufficient to meet domestic demand, forcing the country to import petroleum products. In fact, Nigeria is the only major oil producing country in the world without adequate domestic refining capacity. Nigeria's state-held refineries (Port Harcourt I and II, Warri, and Kaduna) have a combined nameplate capacity of $445,000 \mathrm{bbl} / \mathrm{d}$, but problems including sabotage, fire, poor 
management and a lack of regular maintenance contribute to the current operating capacity of less than 100,000 bbl/d [12]. The government owned refineries are Complex Conversion types that have cracking units in addition to the Atmospheric Distillation Unit and Hydro-skimming unit. These have ability to produce more PMS. These refineries and their installed capacities are stated below and in Figure 1.

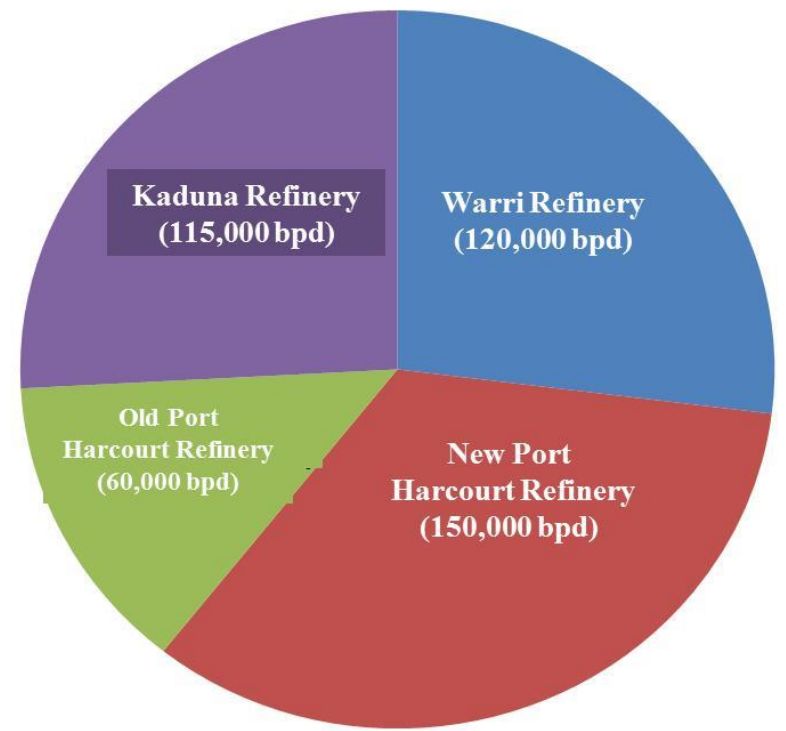

Figure 1: Operational refineries in Nigeria with total installed capacity of 445,000 barrels $\left(24,000 \mathrm{~m}^{3}\right)$ per day.

NNPC produces linear alkyl benzene, benzene, heavy alkylate and deparafinated kerosene at its Kaduna Refinery complex. Linked to the Warri Refinery are a 35,000 metric ton per annum (mtpa) polypropylene plant and an 18,000-mtpa carbon black plant.

The four refineries are at advanced age and invariably plagued by lack of proper maintenance. Consequently they are known to be operating at only about 30\% capacity and producing only about 1.6 billion liters of PMS per year out of the estimated over 18.8 billion liters of PMS per year needed by the country.

The huge deficit in the supply and demand chain is closed through the importation of petroleum products especially premium motor spirit (PMS) or petrol. Other factors poised to increase this PMS supply and demand deficit include higher consumption due to increase in the number of cars on the Nigerian road as a result of increase in the living standard of Nigerians. Another corollary and consequent factor to the above is the need for constant power supply for domestic use and to guarantee power for uninterrupted production of goods and services in the semi-developed Nigeria. Unfortunately, the national electricity generating and distribution companies are known to be incapable of meeting the power needs of these two vital sub-sectors of the Nigerian economy. These sub-sectors virtually resort to running generating sets and industrial plants with PMS and diesel which further increases the PMS importation.

The development agenda of the Nigerian State is to achieve significant economic growth over the next few years up to and beyond the year 2020. Government expectations are for the economy to be one of the largest in the world - specifically one of the 20 largest economies in the world - by 2020 . In order to achieve this development plan, the government has pursued a National Development Agenda known as the National Vision 2020. This vision expects the economy to achieve double-digit growth rates of 13.8 per cent per annum up to 2020 [13]. The growth drivers are the agricultural and industrial sectors over the mediumterm while the end-time growth is expected to be driven by the manufacturing and service sectors.

One of the economic sabotage in Nigeria is the operation of illegal refinery $[14,15]$. To address the issue the Nigerian government plan to liberalize participation in its proposed establishment of modular refineries. The country's Vice President was quoted "Federal government would establish modular refineries in the Niger Delta to drive its development strategy for the region". According to him, youths involved in the illegal refining of crude oil would be employed in the modular refineries to be established by the government in the region" [16].

As a policy, the Federal Government is encouraging private investors to establish modular and conventional refineries as means of, not only eradicating the petroleum products shortfall but also to ensure Nigeria evolves to be a net exporter of petroleum products. The government obvious encouragement for the establishment of modular refineries is one of the means to achieve this objective. In response to the call of the Federal Government, Dangote Refinery Limited planned the construction of $650,000 \mathrm{bpd}$ refinery that will eventaually come into operation by 2020. In addition, the Federal Government has also given approval for the establishment of 10 modular refineries in the Niger Delta area.

However, at various economic and investment meetings, it has been ascertained that the establishment of modular refinery will not be economically viable or may not be able to withstand global economc competitiveness by 2020 especially when the revamping of the present refineries to produce their established capacity of $445,000 \mathrm{bpsd}$ and establishment of Dangote 650,000 bpsd refinery come on stream by 2019. This paper provides analysis of the current state of the refining sector and the refining

Vol. 37, No. 4, October, 2018 
revolution that will take place within the next 3-5 years. The paper draws attention to the existing gaps in the supply of refined petroleum products in Nigeria most especially premium motor spirit (PMS) and highlights the sizeable potential for domestic refining of petroleum products. Lastly, this paper highlights refining asset and structural commercial considerations for investors in the area of modular refinery construction and operation.

\subsection{The Modular Refinery Approach}

Petroleum refineries are very large industrial complexes that involve many different processing units and auxiliary facilities such as utility units and storage tanks. Each refinery has its own unique arrangement and combination of refining processes largely determined by the refinery location, desired products and economic considerations [9]. In addition this uniqueness is also determined by the crude type being refined. There are most probably no two refineries that are identical in every respect [10]. Refineries come in configurations - ranging from small topping and reforming refineries to sophisticated complex refineries. Operating capacity wise, refineries are categorized as modular capacities of $500-50,000$ bbls/day) and conventional conversion complex type with capacities above 100,000 bpsd. Some modern petroleum refineries process as much as 800,000 to 900,000 barrels $(127,000$ to 143,000 cubic meters) per day of crude oil [11]. All refineries, in spite of the size, perform three basic steps which are Separation (fractional distillation), Conversion (cracking and rearranging the molecules), and Treatment [11]. Because of the high capacity, many of the units operate continuously, as opposed to processing in batches, at steady state or nearly steady state for months to years.

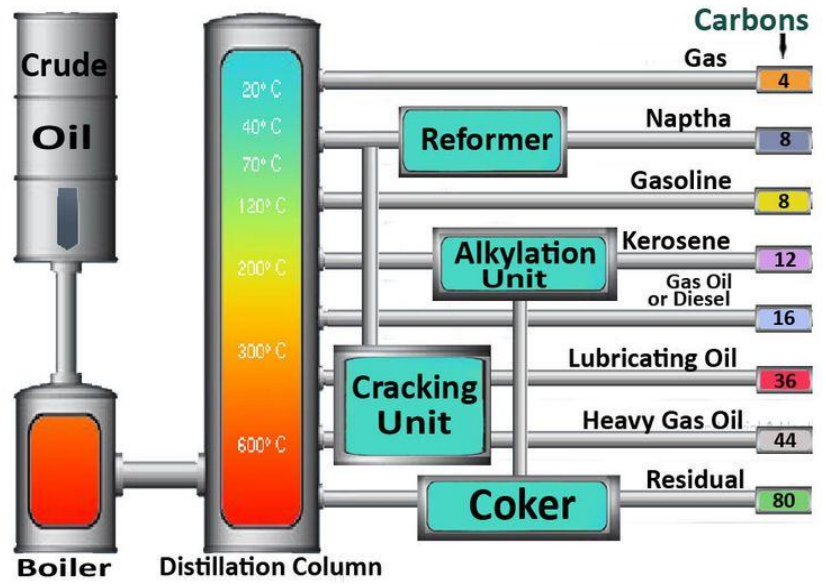

Figure 2: Schematic diagram of a Petroleum Refinery

[17].
The high capacity also makes process optimization and advanced process control very desirable [8]. The schematic diagram of petroleum refinery is shown in Figure 2. The petroleum refineries separate crude oil into constituent fractions by the process of distillation. Petroleum products are usually grouped into three categories: light distillates (LPG, gasoline and naphtha), middle distillates (kerosene and diesel), heavy distillates and residuum (heavy fuel oil, lubricating oils, wax and tar). This classification is based on the methods employed in crude oil distillation and separation into fractions (called distillates and residuum) [18]. The component fractions and their respective volume percentages for one barrel of the Bonny Light Crude are shown in Table 1. Figure 3 and the relevant chart show products from a barrel of low sulfur crude oil (such as the Bonny Light) by the United States refineries using the Catalytic Cracking with Medium Conversion refining technology.

According to Fahim M. A. et. al. [19], in terms of complexity and technology, refineries have three configurations which increase in complexity starting with Topping Refinery, Hydroskimming/Topping refinery to the Catalytic Cracking Refinery with Medium Conversion. The figures 4 to 6 below illustrate the basic configurations and their respective yields for Light Crude oil.

It is noteworthy here that the products yield and number increase with complexity and for the Topping Refinery, common with certain range of modular refineries, to be viable, it must be designed for maximum diesel yield from the crude oil stock.

Table 1: Products made from a Barrel of Bonny Light Crude Oil [20].

\begin{tabular}{lll}
\hline $\begin{array}{l}\text { Product } \\
(1)\end{array}$ & $\begin{array}{l}\text { Temperature Range } \\
{ }^{0} \mathrm{C}\left({ }^{\circ} \mathrm{F}\right)(2)\end{array}$ & $\begin{array}{l}\text { \% Vol. Yield } \\
(3)\end{array}$ \\
\hline LPG & $<15\left(59^{\circ} \mathrm{F}\right)$ & 0.98 \\
Light Gasoline & $\left(55-175^{\circ} \mathrm{F}\right)$ & 4.25 \\
Light Naphtha & $\left(175-300^{\circ} \mathrm{F}\right)$ & 13.73 \\
Heavy & $\left(300-400^{\circ} \mathrm{F}\right)$ & 10.12 \\
Naphtha & $\left(400-500^{\circ} \mathrm{F}\right)$ & 13.28 \\
ADK & $\left(500-650^{\circ} \mathrm{F}\right)$ & 22.69 \\
AGO & $\left(650-800^{\circ} \mathrm{F}\right)$ & 16.81 \\
Light Vacuum & \\
$\begin{array}{l}\text { Oil } \\
\text { Heavy }\end{array}$ & $\left(800-1050^{\circ} \mathrm{F}\right)$ & 13.26 \\
Vacuum Oil & & 4.96 \\
Residue & $>\left(1050^{\circ} \mathrm{F}\right)$ & \\
\hline
\end{tabular}


Table 2: Differences Between Modular and Conventional Refineries

\begin{tabular}{|c|c|c|}
\hline Comparing Factors & Modular Refinery & Conventional Refinery \\
\hline Production capacity & 4,000 to $50,000 \mathrm{bpd}$ & Above $120,000 \mathrm{bpd}$ \\
\hline Construction period & 12 to 18 months & $2-5$ years \\
\hline Operational flexibility & flexible to meet demand changes & Complex \\
\hline Products expectation & $\begin{array}{l}\text { Unleaded Gasoline, Diesel, Kerosene, and Fuel } \\
\text { Oil }\end{array}$ & $\begin{array}{l}\text { Unleaded Gasoline, Diesel, Kerosene, } \\
\text { and Fuel Oil, Lubricating oil, waxes } \\
\text { and asphalt (Caters for all range of } \\
\text { products). }\end{array}$ \\
\hline Construction process & $\begin{array}{l}\text { Parts or equipment are constructed in modules } \\
\text { designed to be transported quickly and easily } \\
\text { anywhere in the world }\end{array}$ & Constructed in place (on site) \\
\hline Operational efficiency & Good & Better \\
\hline Land size (take) & Limited refinery project land space & Maximum land take \\
\hline Cost of installation & Low or minimal installation cost & High cost of installation \\
\hline Return on Investment & Quicker investment recovery & Longer period \\
\hline
\end{tabular}

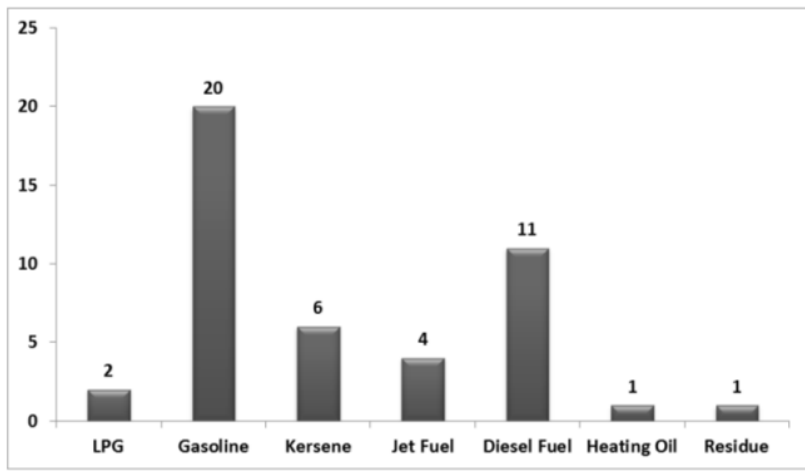

Figure 3(a): Products from ONE Barrel of Low Sulfur Crude Oil Volume in Gallons

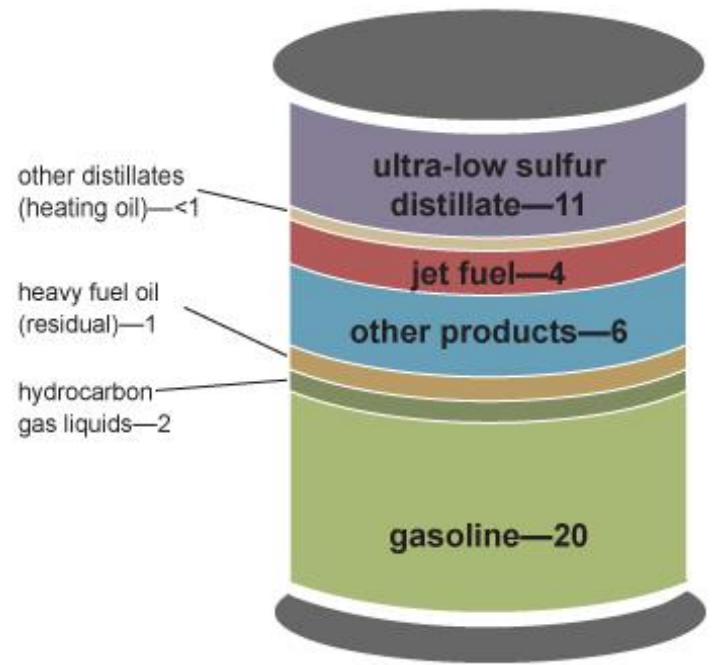

Figure 3(b): Products made from a Barrel of Low Sulfur Crude Oil in a Convectional Refinery [21].

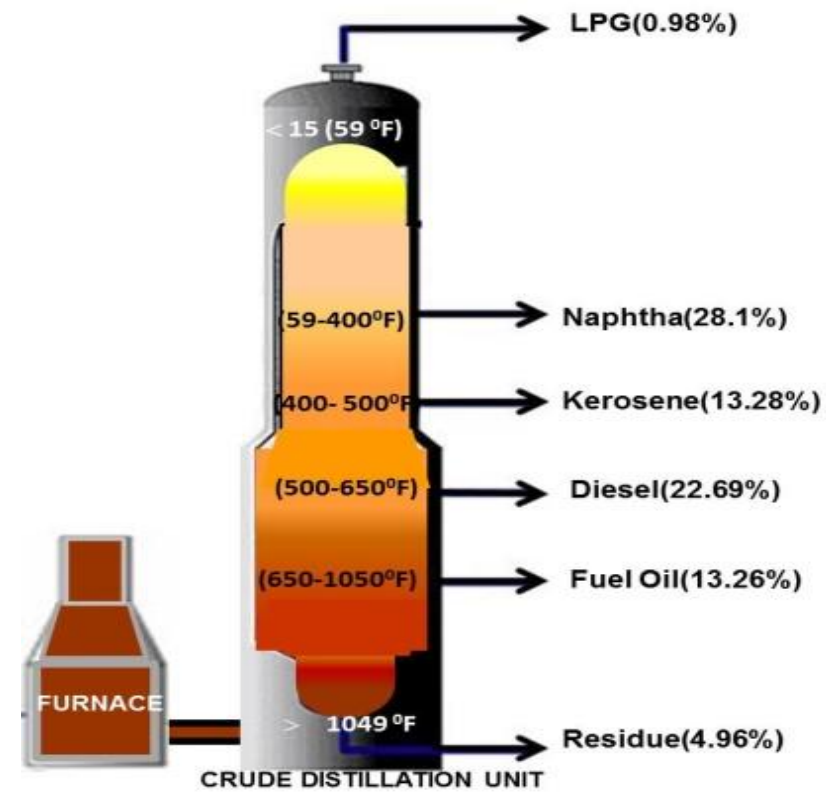

Figure 4: Topping Refinery Configuration and Yield

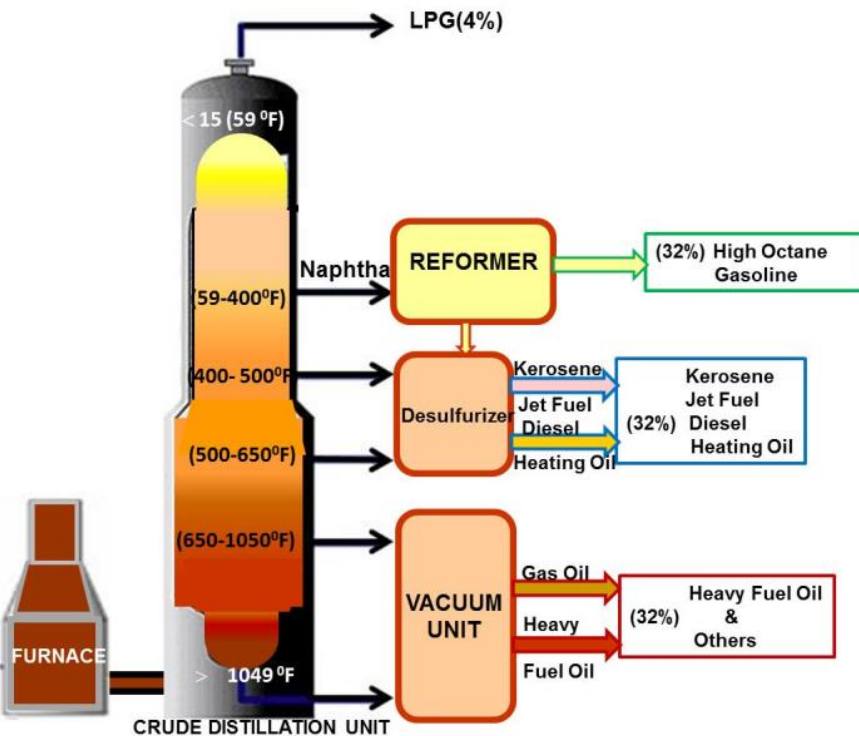

Figure 5: Hydroskimming/Topping Refinery and Yield 


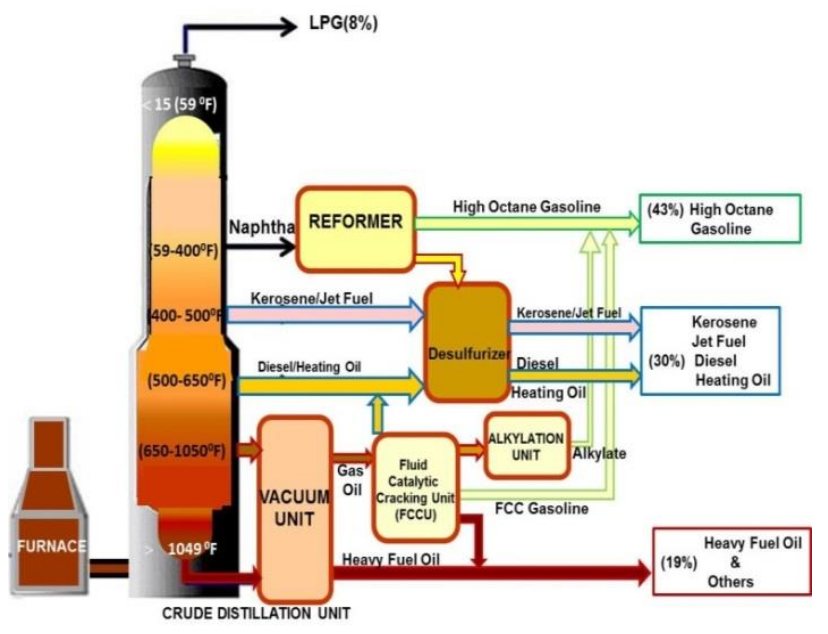

Figure 6: Medium Conversion: Catalytic Cracking and Yield

Operating capacity wise, refineries are categorized as modular and conventional conversion (complex type with capacities above 100,000 bpsd). Major and majority of refineries are basically Conversion Complex types while minorities are Modular. A modular refinery is low capacity refinery of 500 to 50,000 bpsd refining capacity. According to Cenam Energy Partners [22], a modular refinery is a refinery whose parts or equipment are constructed in modules designed to be easily transported quickly and easily anywhere in the world and comes in a variety of sizes with capacities that range from 500 to 30,000 barrels per day. Major differences between modular and conventional refineries are as presented in Table 2.

\section{STUDY METHODOLOGY}

This study was majorly conducted based on the analysis of secondary data collated from the following sources:

1. NNPC Monthly Financial and Operations Report [12].

2. National Bureau of Statistics Petroleum Products Consumption Statistics in Nigeria OPEC Annual Statistical Bulletin [23].

3. Data on Nigeria's Gross Domestic Product (GDP) in Purchasing Power Parity (PPP) and Energy Intensity (EI) [24].

4. Technological and economic data on the modular refinery plant alternative (US Department of Energy, Energy Information Agency EIA [7].

5. Energy planning and foresight analysis methodology was used to determine national petroleum energy demand and petroleum products forecasts (in billion litres) from 2014 - 2020 (US Department of Energy, Energy Information Agency EIA [7].
The period for data analysis is between 2010 - 2016 and projected to 2017 and basic data collated include crude oil supplied to and processed by the local refineries, PMS produced, PMS Imported and PMS Supplied. Other factors incorporated and considered include the Federal Government policy drive towards effectively making the country petroleum products net exporter through the etablishment of modular refineries.

\section{RESULTS AND DISCUSSION}

\subsection{Current Production of PMS From Local Refineries in Nigeria}

In Nigeria there are four refineries: two situated in Port Harcourt and one each in Warri and Kaduna. The refineries have a combined installed capacity of 445,000 bpd. In 1983, the Port Harcourt refinery with 60,000 bpd name plate CDU capacity and the tankage facilities were acquired by NNPC from SHELL. Subsequently, a new 150,000 bpd export refinery was built in 1988 and commissioned in 1989. Therefore, the current combined installed capacity of PHRC is 210,000 bpd. The installed capacities of KRPC and WRPC are 110,000 bpd and 125,000 bpd respectively. NNPC produces linear alkyl benzene, benzene, heavy alkylate and deparafinated kerosene at its Kaduna Refinery complex. Linked to the Warri Refinery are a 35,000 metric ton per annum (mtpa) polypropylene plant and an 18,000-mtpa carbon black plant.

The four refineries are at advanced age and invariably plagued by lack of proper maintenance. Consequently they are known to be operating at only about 30\% capacity [25]. and producing only about 1.6 billion liters of PMS per year as shown in Figure 7 [12, 23].

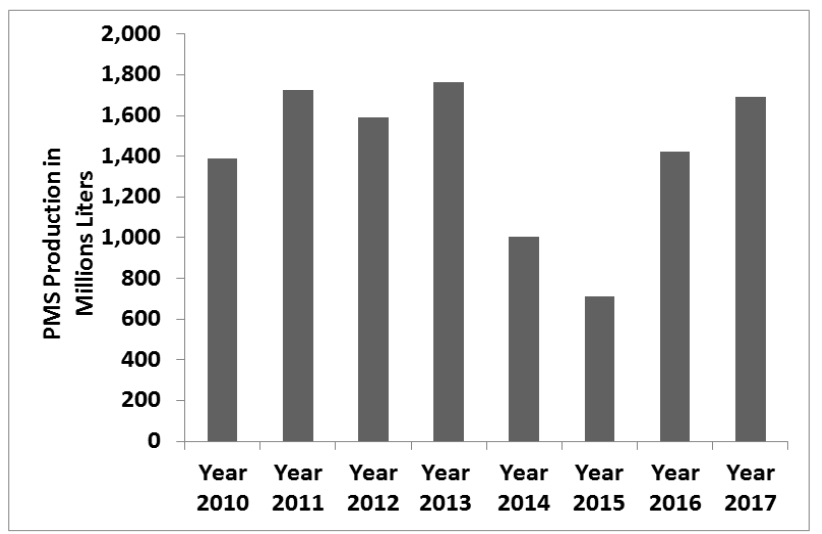

Figure 7: Nigerian Petroleum Products Local Production 
Table 3: Bonny Light Crude Typical Yields

\begin{tabular}{llll}
\hline Product & $\begin{array}{l}\text { Hydro - } \\
\text { skimming wt.\% }\end{array}$ & $\begin{array}{l}\text { NEW } \\
\text { cracking.wt \% }\end{array}$ & $\begin{array}{l}\text { USA cracking } \\
\text { vol. \% }\end{array}$ \\
\hline $\begin{array}{l}\text { LPG } \\
\text { Naphtha \& }\end{array}$ & 0.4 & 2.6 & 3.4 \\
$\begin{array}{l}\text { Gasoline } \\
\text { Jet fuel \& }\end{array}$ & 18.5 & 30.1 & 57.3 \\
$\begin{array}{l}\text { Distillate } \\
\text { Fuel }\end{array}$ & 52.9 & 55.2 & 35.3 \\
\% Sulphur & 24.9 & 6.7 & 7.2 \\
\hline
\end{tabular}

\subsection{Current PMS Consumption in Nigeria}

In consideration of a daily average of 51.5 millions liters consumed in the year 2017, the National Bureau of Statistics puts the consumption of PMS per year at 18.81billion liters $[12,23]$. However by the year 2020, PMS consumption will be $23,033,197,500$ liters if the current consumption rate of 700,000,000 liters/year as revealed by this study and the average annual rate of population change of 2.67 percent are sustained [26]

\subsection{Production of PMS From Local Refinery with Increased Production Capacity}

Our analysis of the PMS production in Nigeria will be based on a typical $32^{\circ}$ API Bonny Light crude oil. The Bonny light is a light low sulphur crude particularly suitable for the production of high yields of good quality petrol and middle distillate (kerosene, jet fuel, diesel) and fuel oil. Its low nitrogen content makes it suitable for direct burning. Its Naphtha with catalytic reforming index $\mathrm{N}+2 \mathrm{~A}$ of about 70 is an excellent feedstock for gasoline production. It has high yields of gasoil with an acceptable cetane index (46) which gives lower ignition delay periods, and good cold properties. It also has good quality cracking feedstock for catalytic cracker. Its residue produces an excellent low sulfur Fuel Oil $(0.5 \% \mathrm{~S})$ Typical products yields from the bonny Light crude are as illustrated in Table 3 depending on the processing technology.

Using international standards the distillation yield of the four (4) Nigerian Refineries for 445,000 bpsd Bonny Light is presented in Table 4. As shown in Table 4, with gasoline and naphtha yields converted to PMS, the Nigerian four refineries working at full capacity for 334 days in a year will give $334 \times 18,678,822=$ $6,238,726,510$ liters of PMS per year. This yield is expected to be higher with the complex conversion refining system of our local refineries. Actually, practical PMS product yields data analysis from crude oil supplies to the local refineries from the NNPC Monthly Financial and Operational Reports, 2017 puts average PMS yield at $31.781 \%$ per crude oil barrel volume. This will give $445,000 \times 0.31781 \times 159 \times 334=$ 7,510,539,948 liters of PMS per year.

\subsection{Analysis of PMS Production From the Dangote 650,000 bpsd Refinery}

Using international standards the distillation yield of Dangote 650,000bpsd refinery is presented in Table 5. Assuming a maintenance period of 31 days in a year, we will have an annual 334 working days the Dangote 650,000 bpsd refinery working for 334 days in a year will give 334 x 27,293,672 =9,112,746,448 liters of PMS per year. In the same token as in the local refineries above with PMS yield at $31.781 \%$ per barrel volume for the conventional refinery, this will give $650,000 \times 0.31781 \times 159 \times 334=10,970,451,610$ liters of PMS.

\subsection{Analysis of PMS Importation and Supply}

In Nigeria, demand gap for PMS is closed through importation. A total consumption/demand of PMS was $18,810,000,000$ billion liters (daily average of $51,534,246.57$ litres) for the year 2017 [23]. Nigerian petrol local production, import and supply is presented in Figure 8. The plots for both the import and supply (consumption) from 2010 to 2016 are as shown in Fugures 9 and 10. The plots indicate a gradual increase of about 700,000,000 liter of PMS per year in both import and supply (consumption). If the epileptic production nature of the local refineries is not halted, this will translate to an increase of 2,800,000,000 liters by the year 2020 with a total importation and supply of $21,612,253,160$ and 23,033,197,507.59 liters of PMS respectively.

\subsection{PMS Production From Dangote Refinery + Full Capacity Production of Local Refineries}

If the Dangote refinery comes on stream by 2020 and all four (4) local refineries working at 88\% ADU efficiency, the total quantity of PMS that will be avaialbe will be $7,510,539,948+10,970,451,610=$ $18,480,991,560$ liters per year. However, premium motor spirit (PMS) projected demand by the end of 2020 is $20,233,197,507.59+2,800,000,000=$ 23,033,197,507.59 litres. Even at this full capacity, Nigeria will still be saddled with importation of $23,033,197,507.59-18,480,991,560=4,552,205,942$ liters of PMS /year.

On the other hand, if the epileptic production nature of the local refineries is not halted, using projected 2017 local refineries production figures of $1,689,366,640$ liters, total PMS production by 2020 will be $1,689,366,640+10,970,451,610=12,659,818,250$ liters. This translates to $23,033,197,507.59$ $12,659,818,250=10,373,379,257.59$ liters of PMS importation. 
Table 4: Distillation Yield of the 4 Nigerian Refineries for 445,000 bpsd Bonny Light with API 32.90

\begin{tabular}{lcccccc}
\hline Product (1) & $\begin{array}{c}\text { Temperature Range } \\
{ }^{0} \mathrm{C}\left({ }^{\circ} \mathrm{F}\right)(2)\end{array}$ & $\begin{array}{c}\% \text { Vol. Yield } \\
(3)\end{array}$ & $\begin{array}{c}\text { Product Yield } \\
\text { in bpsd }\end{array}$ & $\begin{array}{c}\text { Product Yield in } \\
\text { Ipsd }\end{array}$ & $\begin{array}{c}\text { Moderate for } \\
\text { ADU 88\% } \\
\text { Efficiency }\end{array}$ & $\begin{array}{c}\text { Refinery Gain } \\
\text { Factor } \times 1.0714\end{array}$ \\
\hline LPG & $<15\left(59{ }^{\circ} \mathrm{F}\right)$ & 0.98 & 4,361 & 693,399 & $610,191.12$ & 653,759 \\
Light Gasoline & $(55-175 \mathrm{~F})$ & 4.25 & & & & \\
Light Naphtha & $\left(175-300^{\circ} \mathrm{F}\right)$ & 13.73 & 124,600 & $19,811,400$ & $17,434,032$ & $18,678,822$ \\
Heavy Naphtha & $(300-400 \mathrm{~F})$ & 10.12 & & & & \\
ADK & $\left(400-500^{\circ} \mathrm{F}\right)$ & 13.28 & 57,850 & $9,198,150$ & $8,094,372$ & $8,672,310$ \\
AGO & $\left(500-650^{\circ} \mathrm{F}\right)$ & 22.69 & $100,970.5$ & $16,054,310$ & $14,127,792$ & $15,136,517$ \\
Light Vacuum Oil & $\left(650-800^{\circ} \mathrm{F}\right)$ & 16.81 & $74,804.5$ & $11,893,916$ & $10,466,646$ & $11,213,904$ \\
Heavy Vacuum Oil & $\left(800-10500^{\circ} \mathrm{F}\right)$ & 13.26 & 59,007 & $9,382,113$ & $8,256,259$ & $8,845,756$ \\
Residue & $>\left(1050^{\circ} \mathrm{F}\right)$ & 4.96 & 22,072 & $3,509,448$ & $3,088,314$ & $3,308,820$ \\
\hline
\end{tabular}

Table 5: Distillation Yield for Dangote 650,000 bpsd Bonny Light with API $32.9^{\circ}$

\begin{tabular}{|c|c|c|c|c|c|c|}
\hline 1 & $\begin{array}{c}\text { Temperature Range } \\
{ }^{0} \mathrm{C}(\mathrm{O} F) \\
(2)\end{array}$ & $\begin{array}{l}\% \text { Vol. } \\
\text { Yield } \\
(3)\end{array}$ & $\begin{array}{c}\text { Product } \\
\text { Yield in bpsd }\end{array}$ & $\begin{array}{l}\text { Product Yield in } \\
\text { lpsd }\end{array}$ & $\begin{array}{l}\text { Moderate for ADU } \\
88 \% \text { Efficiency }\end{array}$ & $\begin{array}{l}\text { Refinery Gain } \\
\text { Factor x } 1.0714\end{array}$ \\
\hline LPG & $<15(590 \mathrm{~F})$ & 0.98 & 6370 & $1,012,830$ & 891290.4 & 954,929 \\
\hline Light Gasoline & $(55-175$ oF $)$ & 4.25 & & & & \\
\hline Light Naphtha & $(175-300$ oF $)$ & 13.73 & 182,000 & $28,938,000$ & $25,465,440$ & $27,283,672$ \\
\hline Heavy Naphtha & $(300-4000 \mathrm{~F})$ & 10.12 & & & & \\
\hline ADK & $(400-500$ oF $)$ & 13.28 & 86,320 & $13,724,880$ & $12,077,894.4$ & $12,940,256$ \\
\hline AGO & $(500-650$ oF $)$ & 22.69 & 147,485 & $23,450,115$ & $20,636,101.2$ & $22,109,518$ \\
\hline $\begin{array}{l}\text { Light Vacuum } \\
\text { Oil }\end{array}$ & $(650-800 \quad \mathrm{OF})$ & 16.81 & 105,170 & $16,722,030$ & $14,715,386.4$ & $15,766,064$ \\
\hline $\begin{array}{l}\text { Heavy Vacuum } \\
\text { Oil }\end{array}$ & $(800-1050$ oF $)$ & 13.26 & 86,190 & $51,455,430$ & $45,280,778$ & $48,513,826$ \\
\hline Residue & $>(1050$ oF $)$ & 4.96 & 32,240 & 19,247280 & 16,937606 & 18,146951 \\
\hline
\end{tabular}

Table 6: Distillation Yield for 10,000 bpsd Hydroskimming Modular Refinery for Bonny Light with API 32.90

\begin{tabular}{|c|c|c|c|c|c|c|}
\hline Product (1) & $\begin{array}{c}\text { Temperature } \\
\text { Range }{ }^{0} \mathrm{C}\left({ }^{0} \mathrm{~F}\right)(2)\end{array}$ & $\begin{array}{l}\text { \% Vol. } \\
\text { Yield (3) }\end{array}$ & $\begin{array}{l}\text { Product } \\
\text { Yield in } \\
\text { bpsd }\end{array}$ & $\begin{array}{l}\text { Product Yield } \\
\text { Litres/year }\end{array}$ & $\begin{array}{l}\text { Moderate for } \\
\text { ADU 88\% } \\
\text { Efficiency } \\
\text { (liters/year) }\end{array}$ & $\begin{array}{c}\text { Refinery Gain } \\
\text { Factor x } \\
1.0714 \\
\text { (liters/year) }\end{array}$ \\
\hline LPG & $<15\left(59^{\circ} \mathrm{F}\right)$ & 0.98 & 98 & $5,204,388$ & $4,579,862$ & $4,906,864$ \\
\hline Light Gasoline & $\left(55-175^{\circ} \mathrm{F}\right)$ & 4.25 & \multirow{3}{*}{2,810} & \multirow{3}{*}{$149,227,860$} & \multirow{3}{*}{$131,320,517$} & \multirow{3}{*}{140,696802} \\
\hline Light Naphtha & $\left(175-300^{\circ} \mathrm{F}\right)$ & 13.73 & & & & \\
\hline $\begin{array}{l}\text { Heavy } \\
\text { Naphtha }\end{array}$ & $\left(300-400^{\circ} \mathrm{F}\right)$ & 10.12 & & & & \\
\hline $\mathrm{ADK}$ & $\left(400-500^{\circ} \mathrm{F}\right)$ & 13.28 & 1328 & $70,524,768$ & $62,061,796$ & $66,493,008$ \\
\hline AGO & $\left(500-650^{0} \mathrm{~F}\right)$ & 22.69 & 2,269 & $120,497,514$ & $106,037,812$ & $113,608,912$ \\
\hline $\begin{array}{l}\text { Residue Fuel } \\
\text { Oil }\end{array}$ & $\left(650-1050+{ }^{0} \mathrm{~F}\right)$ & 34.95 & 3,495 & $185,605,470$ & $163,332,814$ & $174,994,777$ \\
\hline
\end{tabular}

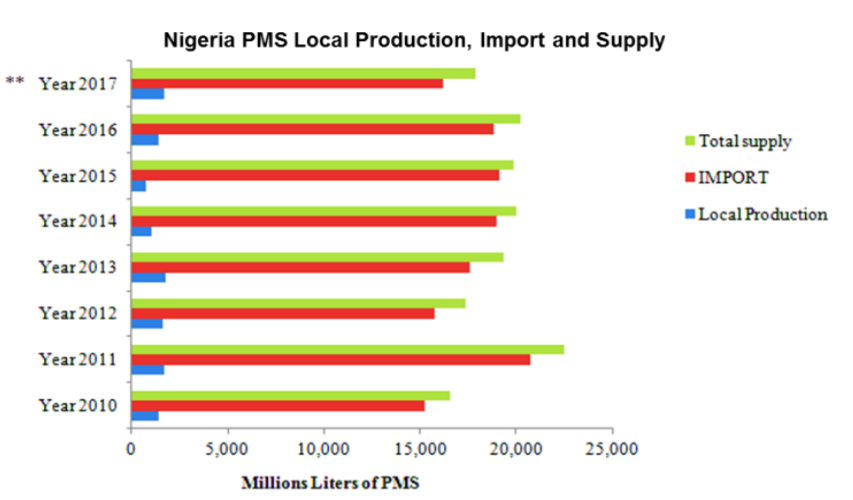

Figure 8: Nigerian Petrol Local Production, Import and Supply

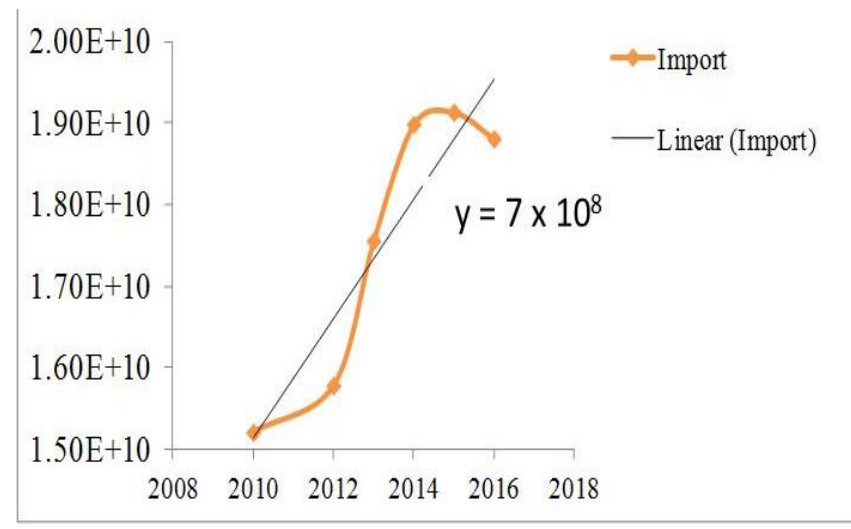

Figure 9: Graph of Yearly Imported PMS

Vol. 37, No. 4, October, 2018 


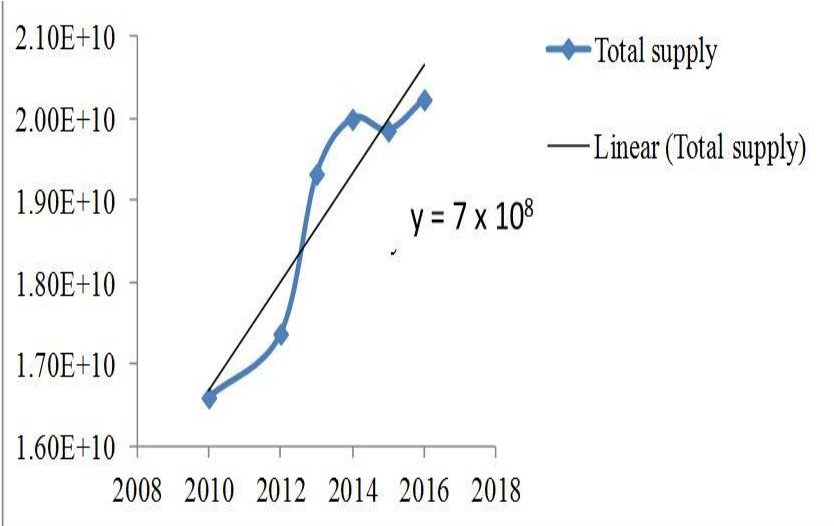

Figure 10: Graph of Yearly Supplied (Consumed)

\subsection{Financial Projections on a 10,000 BPD Modular Refinery (MR)}

A typical 10,000bbls/day Hydroskimming/Topping modular refinery with a Catalytic Reforming unit providing PMS production capabilities is estimated at a maximum of $\$ 100 \mathrm{M}$. Yields from 10,000 bpsd modular Hydroskimming refinery will yield products as in Table 6.

The financial projections presented here are based on the following assumptions

i. Yearly production working days $=334$ days (quite reasonable, based on the, $10,000 \mathrm{bbls} /$ day refinery technology)

ii. $\quad$ Exchange rate $=\mathrm{N} 305 / \$$

iii. Petroleum Products Wholesale Prices below

Table 7: Comparative Prices of Petroleum Products

\begin{tabular}{lccc}
\hline Product & $\begin{array}{c}\text { Price }(\mathrm{N}) \\
\text { /Litre }^{*}\end{array}$ & Equivalent(\$)/Litre & $\begin{array}{c}\text { US Price } \\
(\text { S)/Litre }\end{array}$ \\
\hline LPG & 130 & $0.361^{* *}$ & 0.248 \\
Gasoline & 135 & 0.375 & 0.673 \\
Kerosene & 180 & 0.5 & 0.51 \\
Diesel & 180 & 0.5 & 0.48 \\
Fuel Oil & 70 & 0.194 & 0.312 \\
\hline
\end{tabular}

*Current Nigerian Petroleum Product Wholesale Prices **Wholesale Price from LNG

*** Source: U.S. Energy Information Administration [21]

Table 8: Revenue Profile of Petroleum Products

\begin{tabular}{llll}
\hline Product & $\begin{array}{l}\text { Year } \\
\text { Vol(litres) }\end{array}$ & $\begin{array}{l}\text { Rate } \\
(\mathrm{N})\end{array}$ & $\begin{array}{l}\text { Yearly } \\
\text { Income(N) }\end{array}$ \\
\hline LPG & $4,906,864$ & 102 & 180680556 \\
Gasoline(PMS) & $140,696,802$ & 135 & $18,994,068,270$ \\
ADK(Kerosene) & $66,493,008$ & 180 & $11,968,741,440$ \\
AGO(Diesel) & $113,608,912$ & 180 & $20,449,604,160$ \\
$\begin{array}{l}\text { Residue Fuel } \\
\text { Oil }\end{array}$ & $174,994,777$ & 70 & $12,249,634,390$ \\
\hline \multicolumn{2}{l}{ Total Revenue per Year } & & $63,842,728,816$ \\
\end{tabular}

Tables 7 and 8 provide necessary data for the financial projections below:

1. Estimated Annual Sales Revenue $=(\$ 209,320,423)$

2. Estimated Annual Cost of Crude oil at $\$ 45 / \mathrm{bbl}$ $10,000 \times 45 \times 305 \times 334=\mathrm{N} 45,841,500,000.00$

3. Gross surplus per annum $63,842,728,816$ $45,292,500,000=\mathrm{N} 18,001,228,816(\$ 59,020,423)$

All the calculations are based on the current exchange rate of N305/dollar, which is the going rate for the importers of petroleum products.

Appendices I and II detail out the financial analysis that shows net income increasing from $\$ 35.6 \mathrm{M}$ in the first year to $\$ 49 \mathrm{M}$ in the fifth year, with dividends beginning to accrue from $\$ 2 \mathrm{M}$ in the first year to $\$ 25 \mathrm{M}$ in the fifth year. Company reserves or cumulative cash will increase from $\$ 1.1 \mathrm{M}$ in the first year to $\$ 20 \mathrm{M}$ in the fifth while all debt finance for the estimated project cost of about $\$ 100$ million will be exited within 5 years. The Special Purpose Vehicle(SPV) company members are expected to raise N100 million for project take-off, thus based on current exchange rate of N360/ dollar, they expect a N7.2 per dividend within the first years of production. As from the sixth year, the local SPV takes over ownership of the JV, thus dividends will increase astronomically.

\subsection{Nigeria Refining Capacity Requirement by 2020}

From section 3.6 Nigeria will still be saddled with importation of $4,255,205,942$ liters of PMS /year. If one (1) barrel of crude oil is distilled 74.73 litres of premium motor spirit (PMS) is produced [7, 24]. It is noteworthy to mention here that the Ogundari refinery must be a Conversion Catalytic Cracking type as earlier illustrated in Figure 6 and Table 4 with 47\% PMS yield. A 10,000 bpd modular refinery will therefore produce 249,598,200 liters of PMS per year. However using the 10,000 bpd MRP(modular refinery plant) with a Hydrotreating Technology type, 140,696802 litres of PMS will be produced in a year.(See Table 7). It means Nigeria will need 4,555,205,942/140,696802 = 33 (thirty-four) $10,000 \mathrm{bpd}$ capacity modular refineries to provide the estimated shortfall.

In the same vein, if the epileptic production of the local refineries persists to the end of year 2020 the number of 10,000 modular refineries required for the PMS shortfall will be 10,373,379,257.59/140696802 = 74 modular refineries.

\section{CONCLUSION}

The study revealed that (i) if the Nigeria four refineries working at full capacity for 334 days in a year will give $445 \times 0.31781 \times 159 \times 334=7,510,539,948$ liters of 
PMS per year. (ii) Assuming a maintenance period of 31 days in a year, the PMS yield at $31.781 \%$ per barrel volume for the Dangote refinery, will give $650,000 \mathrm{x}$ $0.31781 \times 159 \times 334=10,970,451,610$ liters of PMS. (iii) If the Dangote refinery comes on stream by 2020 and all four (4) local refineries working at $88 \%$ ADU efficiency, the total quantity of PMS that will be avaialbe will be $7,510,539,948+10,970,451,610=$ $18,480,991,560$ liters per year. (iv) The projected demand of PMS by 2020 is at $20,233,197,507.59+$ $2,800,000,000=23,033,197,507.59$ liters. (v) By the year 2020, with PMS demand at 23,033,197,500 liters, Nigeria will still be saddled with PMS importation of 4,555,205,940 liters and this will also translate to a total of 33 modular refineries of 10,000 bpsd capacity. (vi) Furthermore, if the epileptic production nature of the local refineries is not halted, PMS importation will be at $10,373,379,257.59$ liters which translate to 74 modular refineries of $10,000 \mathrm{bpsd}$

The study also carried out financial analysis of a typical 10,000 bpsd modular refinery which reveals net income that shows net income increasing from $\$ 39 \mathrm{M}$ in the first year to $\$ 49 \mathrm{M}$ in the fifth year, with dividends beginning to accrue from $\$ 4 \mathrm{M}$ in the first year to $\$ 30 \mathrm{M}$ in the fifth year. Company reserves or cumulative cash will increase from $\$ 9 \mathrm{M}$ in the first year to $\$ 44 \mathrm{M}$ in the fifth while all debt finance for the estimated project cost of about $\$ 100$ million will be exited by the end of the fourth years.

Therefore, the refining business in Nigeria remains unsaturated beyond 2020. The modular refineries remains economically viable and competitive and the revamping of the local refineries and the Dangote 650,000 bpsd refinery pose no threat. The Modular Regime needs to thrive as it remains the sure road from importation to the export league in Nigeria.

\subsection{Recommendations}

It is recommended that the Federal Government should augment efforts in providing investment incentives to lure investors in the modular refinery sector of the economy with an added view of not only satisfying the Nigerian PMS demand but also making Nigeria a net exporter of petroleum products.

Both the NNPC and ALL other crude oil producers in Nigeria (IOCs and Marginal field operators) must support and key in to the Federal Government modular refinery initiative by giving crude oil supply guarantees to modular refineries investors.

Investment in the establishment of modular refinery is huge and this is a major scare. Government must therefore provide guarantees in both financial arrangement and feedstock supply to encourage local investors and their offshore financiers.

In the same vein, local investors and technical experts in the field must team up and synergize their resources to venture into this new area of investment in the oil and gas sector of our economy.

Finally, the Federal Government must intensify efforts to revamp the existing four(4) local refineries to produce at full capacity on or before 2020

\section{REFERENCES}

[1] Okoko, K. A. B., and J. N. Nna. "Emerging trends and community perception in the Nigerian oil industry", Nigerian Journal of Oil and Politics (2): $44-54,1998$.

[2] Akinbami, J.F.K. "An Analysis of the Demand and Supply of Electricity and the Greenhouse Gases Emissions of the Nigerian Electrical Power Industry", Ph.D. Thesis, Technology Planning and Development Unit (TPDU), Obafemi Awolowo University, Ile- Ife, Nigeria, 2003.

[3] Campbell, C. J. "The Essence of Oil \& Gas Depletion": collected papers and excerpts. Vol. 19. Multi Science Publishing Company Limited, 2003.

[4] Heinberg, R. "The party's over: oil, war and the fate of industrial societies", New Society Publishers, 2005

[5] Odell, P. R. "Why carbon fuels will dominate the 21st century's global energy economy", Vol. 5. Brentwood: Multi-Science Publishing Company, 2004.

[6] Milbrandt, A. and Overend, R. P. "The future of liquid biofuels for APEC economies". Report prepared for APEC Energy Working Group, 2008.

[7] U.S. Energy Information Administration (EIA, 2014). "Refiner Petroleum Product Prices by Sales Type", $\quad$ https://www.eia.gov/dnav/pet/ pet pri refoth dcu_nus_m.htm, Accessed January 18, 2018.

[8] Colwell, R. "Oil refinery processes: a brief overview". Process Engineering Associates, LLC, http://www.processengr.com, Accessed January $18,2018$.

[9] Gary, J. H. and Handwerk, G.E. "Petroleum Refining Technology and Economics (2 ${ }^{\text {nd }}$ Edition)", Marcel Dekker, Inc. 1984.

[10] Leffler, W. L. "Petroleum refining for the nontechnical person (2nd Edition)", PennWell Books. 1985.

[11] Kane, R. D. "Corrosion in Petroleum Refining and Petrochemical Operations, Corrosion: 
Environments and Industries", Vol 13C, ASM 646 Handbook, ASM International, p 967 - 1014, 2006.

[12] NNPC Monthly Financial and Operations Report 2017. http://nnpcgroup.com/NNPCBusiness/\% 20BusinessInformation/PerformanceData/Monthl yPerformanceData/tabid/617/FolderID/211/Defa ult.aspx, Accessed January 18, 2018.

[13] Obadan, M. I. “Nigeria Vision 20:2020: Challenges and Prospects", Summary of a Presentation at the NISER Research Seminar Series (NRSS) at the Nigerian Institute for Social and Economic Research, Ibadan, August 13. 2013.

[14] Obi, C. L. "Ethnic Minority Agitation and the Specter of National Disintegration", 2002.

[15] Ite, U. E. "Multinationals and corporate social responsibility in developing countries: a case study of Nigeria, Corporate Social Responsibility and Environmental Management", 2004.

[16] Adeosun, 0 and Oluleye. "The Bottom- up Refining Revolution", Pricewaterhousecoopers Limited. https://www.pwc.com/ng/en/assets/pdf/thebottom-up-refining- revolution-part1.pdf, Accessed January 19, 2018.

[17] Chaudhuri, U R. "Fundamentals of petroleum and petrochemical engineering", 2011

[18] Drobny, S. "The Real Economics of Oil". https://www.huffingtonpost.com/sheldondrobny/the-real-economics-of-oil_b_24108.html, Accessed January 19, 2018.

[19] Fahim M. A., Al-Sahhaf, T. A., Elkilami, A. S. "Fundamentals of Petroleum Refining", Elsevier, 2009.
[20] Toboc. "Bonny Light Crude Assay", Crude Suite

http://www.toboc.com/images/pdf/624149.pdf, Accessed January 19, 2018.

[21] United States Energy Information Agency (EIA, 2017). "Independent Statistics and Analysis".

https://www.eia.gov/energyexplained/index.cfm ?page=oil_refining, Accessed January 19, 2018.

[22]. Cenam Energy Partners(2014). "The Case for Modular Mini Refineries". www.cenamenergypartners.files.wordpress.com, Accessed January 19, 2018.

[23] National Bureau of Statistics. "Petroleum Products Consumption Statistics in Nigeria".

http://nigerianstat.gov.ng/download/467, Accessed January 19, 2018.

[24] Ogundari, I. O. "Techno-Economic Analysis of Sustainable Biofuel Development in Nigeria". Ph.D. Thesis, African Institute for Science Policy and Innovation (AISPI), Obafemi Awolowo University, Ile-Ife, Nigeria, 2014.

[25]. Okafor. E. E. "Corruption and implications for 688 industrial development in Nigeria", African Journal of Business Management. Vol.7 690 (29), pp. 2916 2924, 2013

[26]. United Nations, Department of Economic and Social Affairs, Population Division. "World Population Prospects": The 2017 Revision, DVD Edition.

https://esa.un.org/unpd/wpp/Download/Standa rd/Population/, Accessed January 19, 2018.

6. APPENDIX I: Projected Five Year Earnings Forecast (\$)

\begin{tabular}{llllll}
\hline Year & Year 1 $(\$)$ & Year 2 $(\$)$ & Year 13(\$) & Year 4 (\$) & Year 5 (\$) \\
\hline Total Sales & $209,320,423$ & $209,320,423$ & $230,252,465$ & $230,252,465$ & $230,252,465$ \\
Cost of Feedstock & $150,300,000$ & $150,300,000$ & $167,000,000$ & $167,000,000$ & $167,000,000$ \\
Gross Margin & $59,020,423$ & $59,020,423$ & $63,252,465$ & $63,252,465$ & $63,252,465$ \\
\hline \multicolumn{5}{c}{ OPERATING COST } \\
\hline Travel, Vacation. & 118,800 & 118,800 & 130,680 & 130,680 & 130,680 \\
Local Admin. \& Sales & 310,801 & 310,801 & 326,341 & 326,341 & 358,975 \\
Local Support, Apts. Etc. & 118,800 & 118,800 & 122,000 & 122,000 & 132,000 \\
Local Refinery Expats Salaries & $1,020,000$ & $1,020,000$ & $1,122,000$ & $1,122,000$ & $1,122,000$ \\
Expats Personnel & 670,000 & 670,000 & 737,000 & 737,000 & 737,000 \\
Operations, General & $2,540,000$ & $2,540,000$ & $2,667,000$ & $2,667,000$ & $2,778,000$ \\
Maintenance, Chemicals, etc. & 133,110 & 133,110 & 119,799 & 119,799 & 110,000 \\
Contract Maintenance(Specialists) & & & & & \\
Operational Contingencies & 399,940 & 399,940 & 359,946 & 359,946 & 350,000 \\
Interest Payments 6\% & $6,000,000$ & $4,200,000$ & $2,400,000$ & 600,000 & 0 \\
\hline
\end{tabular}




\begin{tabular}{llllll}
\hline Year & Year 1 $(\$)$ & Year 2 $(\$)$ & Year 13(\$) & Year 4 (\$) & Year 5 (\$) \\
\hline Premium on All Risk Insurance & 510,000 & 510,000 & 510,000 & 510,000 & 510,000 \\
Depreciation, (12.5 years) & $8,000,000$ & $8,000,000$ & $8,000,000$ & $8,000,000$ & $8,000,000$ \\
Total Operating Cost & $19,821,451$ & $18,021,451$ & $16,494,766$ & $14,694,766$ & $14,228,655$ \\
Income before Tax (IBT) & $39,198,972$ & $40,998,972$ & $46,757,699$ & $48,557,699$ & $49,023,810$ \\
Income Tax per Year (\%IBT) & 0 & 0 & 0 & 0 & 0 \\
Net Income per Year & $39,198,972$ & $40,998,972$ & $46,757,699$ & $48,557,699$ & $49,023,810$ \\
& & & & & \\
\hline
\end{tabular}

The following assumptions have been made in the computations:

1. Raw material price projections are based on $\$ 45.00 /$ bbl for yrs I \&II, $\$ 50 /$ bbl for yrs III,IV \& V

2. Product sales based on current Nigerian prices are: PMS - $\$ 0.44 /$; Kero $\$ 0.59 /$; Diesel $\$ 0.59 /$ bbl; Residual $\$ 0.23 / \mathrm{bbl}, 10 \%$ increase has been computed for years III, IV \& V.

7. APPENDIX II: Five Years Income and Expenses

\begin{tabular}{llllll}
\hline \multicolumn{7}{c}{ SOURCE OF CASH } & & \\
\hline Year & Year 1 (\$) & Year 2 (\$) & Year 3 (\$) & Year 4 (\$) & Year 1 (\$)5 \\
Net Income & $39,198,972$ & $40,998,972$ & $46,757,699$ & $48,557,699$ & $49,023,810$ \\
Depreciation & $8,000,000$ & $8,000,000$ & $8,000,000$, & $8,000,000$ & $8,000,000$ \\
\hline Total & $47,198,972$ & $48,998,972$ & $54,757,699$ & $56,557,699$ & $57,023,810$ \\
\hline \multicolumn{7}{c}{ USE OF CASH } & & & \\
\hline Capital Improvements \& Contingency & $3,000,000$ & $5,000,000$ & $6,000,000$ & $9,000,000$ & $10,000,000$ \\
Term Loan Refund & $30,000,000$ & $30,000,000$ & $30,000,000$ & $10,000,000$ & 0 \\
Dividends & $4,000,000$ & $5,000,000$ & $8,000,000$ & $25,000,000$ & $30,000,000$ \\
Board of Directors Allowances & $1,000,000$ & $2,000,000$ & $3,000,000$ & $4,000,000$ & $5,000,000$ \\
\hline Total & $38,000,000$ & $42,000,000$ & $47,000,000$ & $48,000,000$ & $45,000,000$ \\
\hline Annual Net Cash Flow & $9,198,972$ & $6,998,072$ & $7,757,699$ & $8,557,699$ & $12,023,810$ \\
\hline Cumulative Cash & $9,198,972$ & $16,197,044$ & $23,954,743$ & $32,512,442$ & $44,536,252$ \\
\hline
\end{tabular}

